\title{
Gp100 Human Melanoma Peptide Vaccine with Incomplete Freund's Adjuvant
}

National Cancer Institute

\section{Source}

National Cancer Institute. gp100 Human Melanoma Peptide Vaccine with Incomplete

Freund's Adjuvant. NCI Thesaurus. Code C16167.

A vaccine consisting of synthetic glycoprotein 100 (gp100) melanoma antigen and incomplete Freund's adjuvant (IFA), an emulsifying agent and immune system stimulant, with antineoplastic activity. Vaccination with gp100 human melanoma peptide vaccine with IFA may stimulate the host immune system to direct cytotoxic $T$ lymphocytes (CTL) against gp100 positive melanoma cells, resulting in decreased tumor growth. (NCI04) 